\title{
REPRODUCTIVE CYCLE OF Leporinus copelandii (Pisces: Anostomidae) FEMALES FROM THE LOWER PARAÍBA DO SUL RIVER BASIN, RJ - BRAZIL
}

\section{Ana Paula Ribeiro Costa ERTHAL ${ }^{1 *}$, Dalcio Ricardo de ANDRADE ${ }^{1}$, Marcella Costa RADAEL ${ }^{2}$, Milton ERTHAL JUNIOR ${ }^{2}$, Eduardo SHIMODA ${ }^{2}$}

\author{
${ }^{1}$ Universidade Estadual do Norte Fluminense Darcy Ribeiro. Campos dos Goytacazes, Rio de Janeiro, Brazil. \\ ${ }^{2}$ Universidade Candido Mendes. Campos dos Goytacazes, Rio de Janeiro, Brazil. \\ *Corresponding author: ana.uenf@gmail.com
}

http://dx.doi.org/10.18571/acbm.091

\begin{abstract}
The aim of this study were investigate the reproductive biology of the fish Leporinus copelandii, a specie at risk of extinction in the lower Paraíba do Sul River basin. During a period of 14 months, a total of 143 females of red-piau were captured, between Itaocara and Campos dos Goytacazes cities (RJ, Brazil). A histological study shows four stages of the oocyte development (I, II, III and IV) and five stages of the reproductive cycle of females: rest (1), initial maturation (2A), intermediary (2B), advanced (2C) and spawned (4) were identified. The pattern of $L$. copelandii oocyte development suggests development type synchronous in two groups, characterizing total spawning. Spawned females were captured in November, two months after the peak of frequency of competent females for reproduction. Histologically, a little occurrence of empty follicles was observed in spawned females. The medium diameter of the type IV oocyte of the spawned females $(1475.1 \pm 884.3 \mu \mathrm{m})$ was significantly larger (Tukey, $\mathrm{P}$ $<0.001 ; \mathrm{VC}=41.73 \% ; \mathrm{n}=259)$ than advanced maturation females $(1202.6 \pm 245.3 \mu \mathrm{m})$, what allows suggesting that the study place probably doesn't represent the reproductive area of $L$. copelandii.
\end{abstract}

Keywords: reproductive biology; red-piau; ovarian development; oogenesis; oocyte; gonadosomatic index.

\section{RESUMO}

O objetivo deste estudo foi investigar a biologia reprodutiva do peixe Leporinus copelandii, uma espécie em risco de extinção na Bacia do rio Paraíba do Sul. Durante um período de 14 meses, um total de 143 fêmeas de piau-vermelho foram capturados, entre as cidades de Itaocara e Campos dos Goytacazes (RJ, Brasil). Um estudo histológico mostra quatro fases do desenvolvimento do oócito (I, II, III e IV) e cinco fases do ciclo reprodutivo de fêmeas: repouso (1), a maturação inicial (2A), intermediário (2B), avançado (2C) e desovado (4) foram identificadas. O padrão de desenvolvimento ovocitário de $L$. copelandii sugere tipo de desenvolvimento sincrônico em dois grupos, caracterizando desova total. Fêmeas desovadas foram capturados em novembro, dois meses após o pico da frequência de reprodução. Histologicamente, pouca ocorrência de folículos vazios foi observada nas fêmeas desovadas. O diâmetro médio do ovócito tipo IV das fêmeas desovadas $(1.475,1 \pm 884,3 \mu \mathrm{m})$ foi significativamente maior (Tukey, $\mathrm{P}<0,001 ; \mathrm{CV}=41,73 \% ; \mathrm{n}=259$ ) do que as fêmeas em níveis avançados de maturação $(1.202,6 \pm 245.3 \mu \mathrm{m})$, o que permite sugerir que o local de estudo, provavelmente não representa a área reprodutiva de $L$. copelandii.

Palavras chave: Biologia reprodutiva; piau vermelho; desenvolvimento ovariano; oogênese; ovócito; índice gonadossomático. 


\section{Introduction}

The Paraíba do Sul River, located in the southeastern Brazil, is one of the most important aquatic systems of South America. It is, approximately, $1,137 \mathrm{Km}$ long, with hydrographic basin around 55,300 $\mathrm{Km}^{2}$ (BIZERRIL et al., 1998; ARAÚJO et al., 2001). It passes through three of the most important Brazilian states: São Paulo, Rio de Janeiro and Minas Gerais. There are small and medium size cities located in all its extension. Despite the fact that this river is an important supplier of water for human consumption, it receives a large amount of organic waste (CARVALHO et al., 1999, MARENGO \& ALVES, 2005).

The red-piau, (Leporinus copelandii) belongs to the Anostomidae family (GARAVELLO, 1979) and is omnivorous fish species. It is known, in the southeastern region, as red-piau because of its red fins. It has good potential for captivity and cultivation and also for sport fishing. This fish has clear and consistent meat appreciated by people. Its population stocks are distributed in all Paraíba do Sul River (BIZERRIL et al., 1998), although presenting low relative incidence (ARAÚJO et al., 1995) due to its population decline (BIZERRIL et al., 1998). A few aspects of its biology are registered in the literature. Nikolski (1963) considers reproduction a link of the fish life cycle, which assures the perpetuation of the species. Its peculiarities are adaptation to several conditions that propitiate the development of the offspring, its preservation and abundance.

Studies on the reproductive biology of the species provide important information for the rationalization of cultivation and in making decisions regarding the protection of natural stocks tools (VAZZOLER, 1996) giving necessary support for the development of programs aimed at the preservation and rational exploitation of fish population in rivers and lakes (PRESTES et al., 2010).

For more information concerning the reproductive biology of red-piau, this paper presents oocyte and gonadal development stages, spawning type and reproductive period of females of Leporinus copelandii in the lower Paraíba do Sul River basin.

\section{Material and Methods}

Females of Leporinus copelandii (Figure 1) were captured in the basin of the lower Paraíba do Sul River, with gill nets of varied meshes, between Itaocara $\left(21^{0} 67^{\prime} \mathrm{S} ; 42^{0} 08^{\prime} \mathrm{W}\right)$ and Campos dos Goytacazes $\left(21^{0} 44^{\prime} \mathrm{S} ; 41^{0} 18^{\prime} \mathrm{W}\right)$ cities (RJ), in monthly samplings, during 13 months, from February of year I to March of year II. The animals were transported for the laboratory in box cooler, and handled soon after.

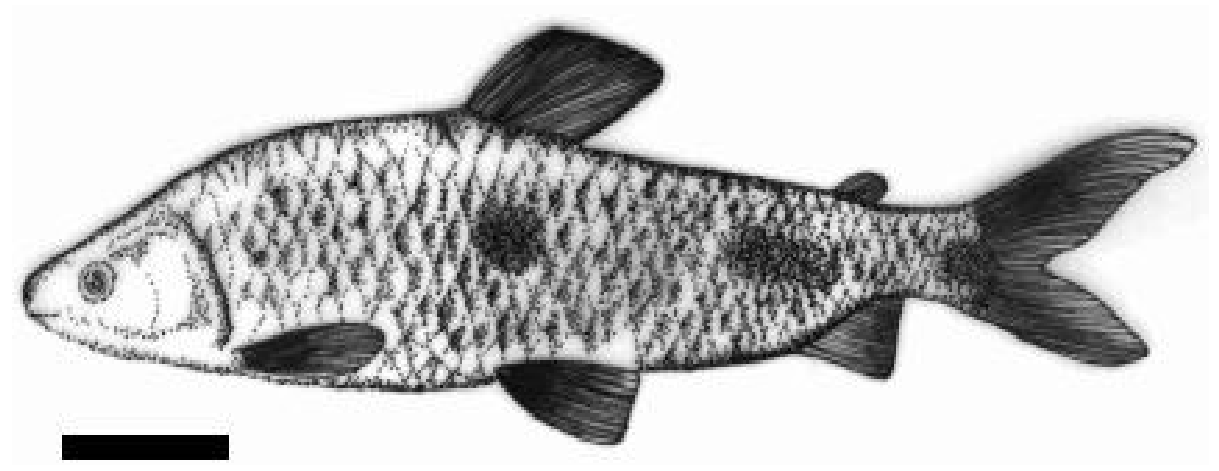

Figure 1: Specimen of Leporinus copelandii (MNUFRJ 20016) captured in Muriaé River, from the Basin of the lower Paraíba do Sul River, RJ - Brazil (bar $=5.0 \mathrm{~cm})$. 


\section{Biomédica Brasiliensia}

The fish were measured and weighed so as to obtain the standard length (SL) and total weigh (TW). After dissection with ventral incision, the color, shape and conformation of the ovaries were macroscopically observed, and, then, weighted (GW). The gonadosomatic relation (GSR) was calculated according to the Vazzoler (1996) (GSR = GW / TW x 100).

For identification of the oocyte development, reproductive cycle stages characterization and spawning type, transverse sections of the left ovary were fixed in Bouin's liquid, conserved in alcohol $70 \%$, dehydrated in increasing concentrations of ethyl alcohol and included in paraffin.

Histological cuts (5 to $7 \mu \mathrm{m}$ of thickness) were obtained and stained with haematoxylin/eosin, according to Luna (1969) and Lopez et al. (1982). The type of spawning was determined by the frequency distribution of reproductive cycle stages and histology of the ovaries (BAZZOLI, 2003).

Entire and spherical oocytes showing sectioned nucleus, histologically, were measured by an ocular micrometry to identify the four stages of the oocyte development (I, II, III and IV). According to oocytes type frequency, five stages of the reproductive cycle were defined: rest (1), initial maturation (2A), intermediary maturation (2B), advanced maturation (2C) and spawned (4), adapted from the classification used by Tavares (1986) and Andrade (1990).

In order to obtain the frequency of the different oocyte types in each stage of the reproductive cycle, all cells were counted on each histological slide.

Descriptive analysis of the values of the gonadosomatic relation and the reproductive cycle stages was made (alpha $=0.05)($ SAEG 7.1, 1997).

\section{Results}

The 143 females of Leporinus copelandii (STEINDACHNER, 1875) show standard length between $19.1 \mathrm{~cm}$ and $35.3 \mathrm{~cm}$ and total weigh between $156.0 \mathrm{~g}$ and $849.5 \mathrm{~g}$.

\subsection{Morphology of the ovaries}

The ovaries of $L$. copelandii present a pair of gonads set in the dorsal portion of the body cavity, ventrally to the kidneys, one on each side of the gaseous bladder. They come separate from the cranial to the posterior portion, where they form a single short duct, opening to the outside through the urogenital pore. Initially, they present laminate format and assume cylindrical-prolonged form in advanced development stage.

Ovaries of $L$. copelandii are covered by simple squamous epithelium and basal laminae and, internally, by the tunica albuginea. It is consisted of fibrous conjunctive contends flat muscular fibers and blood vessels The albuginea is projected into the ovary toward the lumen, forming ovigerous lamellae, which has oocyte at various stages of development.

\subsection{Oocyte development stage}

The second oogonia of $L$. copelandii were found grouped in nests in the walls of the ovigerous lamellae. They possessed round form, big clear nucleus, prominent nucleoli, scarce and a little stained cytoplasm. They were the smallest cells of the oogenesis in the ovaries.

Oocyte of $L$. copelandii was classified in four maturation stages: type I, II, III and IV oocyte. Increase in oocyte diameter and changes in this morphology were observed in maturation process (Table 1). 
Table 1: Oocyte diameter (average \pm standard) for stage reprodructive cycle of Leporinus copelandii.

\begin{tabular}{|c|c|c|c|c|}
\hline \multirow[b]{2}{*}{ Stages } & \multicolumn{4}{|c|}{ Oocyte diameter $(\mu \mathrm{m})$ (average \pm standard $)$} \\
\hline & Oocyte I $^{*}$ & Oocyte II $^{*}$ & Oocyte III $^{*}$ & Oocyte IV $^{*}$ \\
\hline 1 & $81.9 \pm 30.7 \mathrm{a}$ & $195.3 \pm 37.6 \mathrm{c}$ & - & - \\
\hline $2 \mathrm{~A}$ & $104.4 \pm 46.9 \mathrm{~b}$ & $240.9 \pm 53.5 \mathrm{ab}$ & $426.7 \pm 94.7 b$ & - \\
\hline $2 \mathrm{~B}$ & $110.8 \pm 30.9 b$ & $222.6 \pm 65.6 b$ & $469.0 \pm 85.4 \mathrm{~b}$ & $896.7 \pm 102.9 \mathrm{a}$ \\
\hline $2 \mathrm{C}$ & $118.8 \pm 47.7 \mathrm{~b}$ & $258.7 \pm 75.6 \mathrm{a}$ & $578.4 \pm 157.4 \mathrm{a}$ & $1202.6 \pm 245.3 b$ \\
\hline 4 & $75.8 \pm 28.0 \mathrm{a}$ & $216.9 \pm 94.7 b$ & $467.9 \pm 102.5 b$ & $1475.1 \pm 884.3 \mathrm{c}$ \\
\hline
\end{tabular}

Squamous follicular cells surrounding each oocyte were distinguished. The zone pellucida of type IV oocyte presented two layers: a thin outer layer and a thicker inner layer with conspicuous transverse striae. In the animal pole of type IV oocyte, the micropylar apparatus was observed. The funnel-shaped showed a shallow vestibule and long micropylar canal (Figure 2).

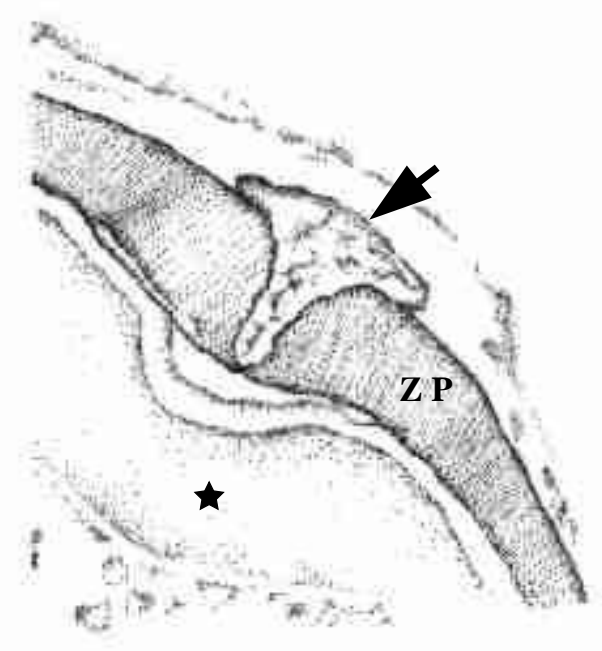

Figure 2: The micropylar apparatus of Leporinus copelandii. Micropylar cell (arrow), Zona Pellucida (ZP) and cytoplasm (star).

\subsection{Reproductive cycle}

The ovarian development was classified in five stages of the reproductive cycle: I rest (1), initial maturation (2A), intermediary (2B), advanced (2C) and spawned (4).

The mature stage was not included in this study because the methodology did not allow its identification duration probably occurs near ovulation (SELMAN \& WALLACE, 1989).

The oocyte types I and II (not vitellogenic) were observed in all stages of the reproductive cycle. In ovaries of females in rest and spawned stage, the type I oocyte was more frequent. The beginning of the vitellogenesis process and the ovaries maturation was characterized by the presence of oocyte with cortical vesicles (type III oocyte). This type occurred at the beginning of maturation (2A stage) and was observed until spawned, always in smallest proportion in the ovaries. In the $2 \mathrm{~B}$ stage (intermediary maturation), IV oocyte was identified, occurring in greater 
proportion in the $2 \mathrm{C}$ stage (advanced maturation) and in smallest proportion in the fourth stage (Figure 3).

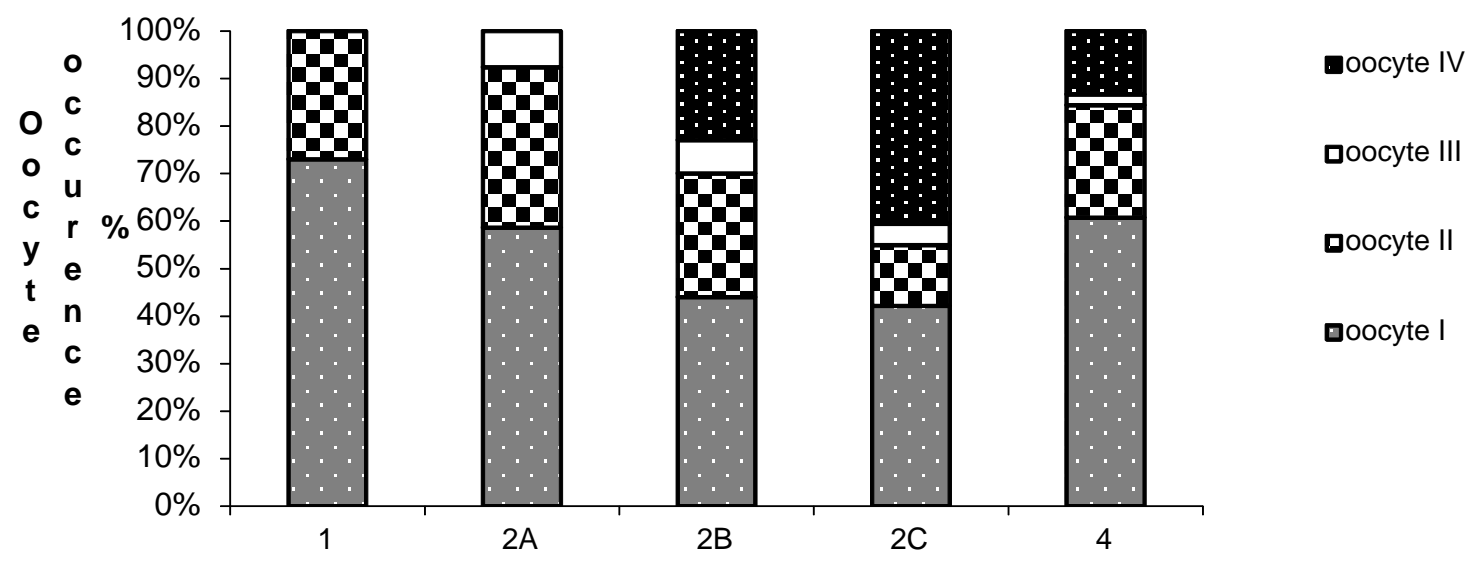

Stages of the Reproductive cycle

Figure 3: Oocyte type occurrence for stage of the reproductive cycle of the Leporinus copelandii, from February/Year I to March/Year II, at the Basin of the lower Paraíba do Sul River, RJ - Brazil.

Spawned stage was determined (Figure 3) by the percentage of occurrence of different oocyte types of ovarian oocytes. In the $2 \mathrm{~B}$ and $2 \mathrm{C}$ gonadal stages, two oocyte groups were identified. The first one was composed of not vitellogenic oocytes $(2 \mathrm{~B}$ stage $=70.0 \% ; 2 \mathrm{C}$ stage $=54.9 \%)$. The other one was composed of vitellogenic oocytes, with one type IV oocyte represented the larger proportion $(2 \mathrm{~B}$ stage $=30.0 \% ; 2 \mathrm{C}$ stage $=45.1 \%)$. This characteristic suggested that $L$. copelandii presented pattern of oocyte development of the type synchronous in two groups, characterizing total spawning for the species.

\subsection{Gonadosomatic relationship}

It was observed gradual increase of the average values of GSR, starting from the rest stage $(0.39 \pm 0.11 ; \mathrm{n}=53)$ (average \pm standard deviation; $\mathrm{n}=$ sample) with peak in the advanced maturation stage $(5.55 \pm 2.76 ; \mathrm{n}=24)$, decreasing, soon after, in the spawned stage $(1.58 \pm 0.65$; $\mathrm{n}=19$ ). The confidence intervals of the GSR average values of the rest and initial maturation stage overlaps identified that this variable, by itself, didn't constitute an efficient indicator in these two stages of the reproductive cycle for species in the data collection area.

The average values of GSR starting increase from August/year I $(2.08 \pm 0.74 ; n=13)$ (average \pm confidence interval; $\alpha=0.05$ ), reaching maximum average value in September/year I $(7.39 \pm 1.93 ; n=6)$ and decreasing in the subsequent months (Figure 4). The period from February to July of year I, probably, could be associated to a phase of gonadal recovery of the previous reproductive cycle and its reorganization for the subsequent one, coinciding with decrease pluviometric levels in the region (Figure 4).

The maximum individual value of the gonadosomatic relation observed among the fishes captured for the present work was GSR $=15.07$ for a female in advanced maturation stage. The female of smallest size, in the advanced maturation stage, presented $\mathrm{SL}=19.1 \mathrm{~cm}$ and $\mathrm{TW}=$ $156.0 \mathrm{~g}$. 


\section{Biomédica Brasiliensia}

The monthly relative frequencies of the reproductive cycle stages of $L$. copelandii females (Figure 4) showed that females in rest stage were captured during the whole study period, except in September and November. Females in 2A stage began to be captured in May; even so it was not possible to determine the beginning of the individuals' recruitment for the following reproductive period, because the sample of April month was only composed of one individual.

Females in 2B stage were captured from July/year I to February/year II, except in September and November of year I, presenting capture peak in August/year I, indicating continuous process of the individuals' recruitment for the reproductive period. Females in $2 \mathrm{C}$ stage were captured in the quarter of August for October/year I, and in January/February/year II, with occurrence of peak in September/year I. This observation allows saying that, in September, it was possible to observe competent females for reproduction, characterizing the beginning of the reproductive period of the species in the study area.

Females, in 4 stage, started being captured in November/year I, two months after the peak of frequency of competent females for reproduction. Histologically, a little occurrence of empty follicles was observed in spawned females. The medium diameter of the type IV oocyte of the spawned females $(1475.1 \pm 884.3 \mu \mathrm{m})$ was significantly larger (Tukey, $\mathrm{P}<0.001$; $\mathrm{VC}=41.73 \%$; $\mathrm{n}=259)$ than advanced maturation females $(1202.6 \pm 245.3 \mu \mathrm{m})$, what allows suggesting that the study place doesn't probably represent the reproductive place of $L$. copelandii. 


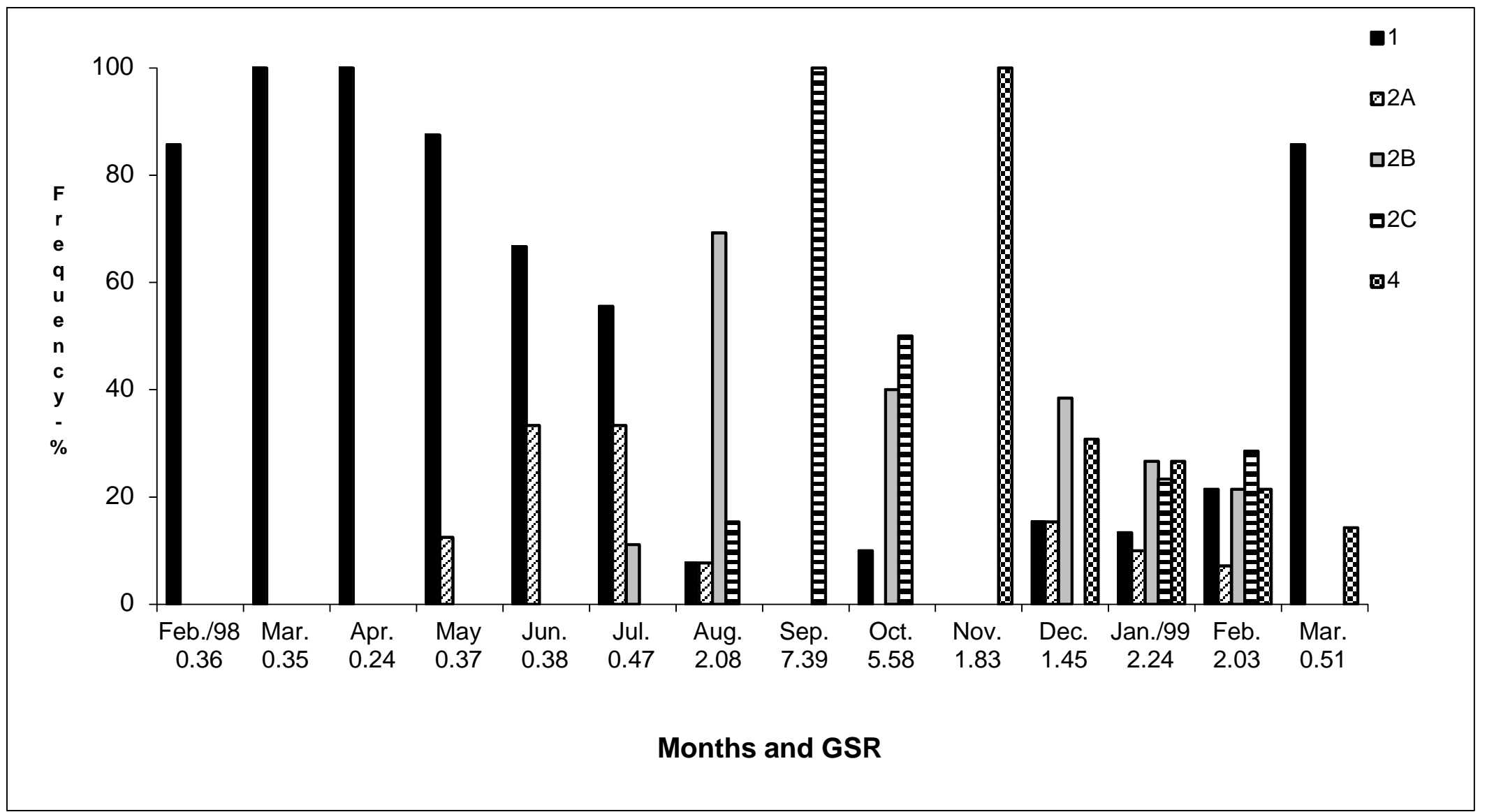

Figure 4: Monthly relative frequency (\%) of the reproductive cycle stages and gonadosomatic relationship of Leporinus copelandii females from the basin of the lower Paraíba do Sul River, RJ - Brazil, from February/Year I to March/Year II. 


\section{Discussion}

The ovaries of Leporinus copelandii are of cystovarian type (HOAR, 1969) and, macroscopically, present characteristics and anatomical relation similar to those described by Diniz (1997) for Leporinus striatus, Leporinus octofasciatus, Leporinus obtusidens and Tavares (1986) and Tavares \& Godinho (1994) for Leporinus piau. The ovarian pattern described for the genus Leporinus is similar to most of the freshwater teleosts fishes despite of small variations that could be observed in the volume, thickness and coloration in different stages of the reproductive ovarian cycle (FERREIRA \& GODINHO, 1990; BENJAMIN, 1996; KOBELKOWSKY, 2012).

Diniz (1997) observed that the ovaries of five species of Leporinus were histologically covered at the surface by the peritoneal and albuginea tunica. The albuginea projections form the ovigerous lamellae, as observed in the present work for L. copelandii. The histological pattern described for the ovaries of $L$. copelandii is similar to that of other teleosts studied by Ferreira \& Godinho (1990), Benjamin (1996) and Teles \& Godinho (1997). However, in species of the genus Semaprochilodus (CHAVES \& VAZZOLER, 1984), the ovaries show more defined distribution of oocytes with the less developed ones located in the periphery of the lamellae, and the more developed, in the center.

The dynamics study of the oogenesis in Brazilian teleosts has been intensified along the last two decades. The primordial germ cells give rise to nests of primary and secondary oogonia through a series of mitotic divisions. The latter enters meiotic division to form the primary oocytes (De VLAMING, 1983). The description of the stages of the oocyte development for $L$. copelandii is similar to those achieved by Tavares (1986), Sato \& Godinho (1988), Bazzoli \& Rizzo (1990), Tavares \& Godinho (1994) and Diniz (1997) for species of the same genus, and for other teleosts as Curimatella lepidura (ANDRADE, 1990), Schizodon knerii (FERREIRA \& GODINHO, 1990), and Mycteroperca venenosa (GARCÍA-CAGIDE \& GARCÍA, 1996), Serrasalmus brandtii (TELES \& GODINHO, 1997) and Pimelodus clarias maculates (FLORES \& ARAYA, 2005).

The oocyte development has been classified as synchronous, group synchronous and asynchronous. The group synchronous is characterized by presenting at least two groups of oocyte in different development stages at same time: a group of unyolked or not vitellogenic and another of yolked oocytes (WALLACE \& SELMAN, 1981; WEST, 1990; VAZZOLER, 1996). The oocyte dynamics of $L$. copelandii follows the group synchronous, which coincides with the results described by L. elongatus (SATO \& GODINHO, 1988) and L. piau (TAVARES \& GODINHO, 1994) from Três Marias Reservoir (MG).

The type of spawning can be defined as the way that the females liberate its mature oocytes during a reproductive period. Considering the dynamics of the oocyte development, the spawning frequency during the reproductive period and the number of these periods along a fish life, the spawning type can be determined by different species (VAZZOLER, 1996). Nevertheless, West (1990) mentions that the type of oocyte development is not also necessarily a fixed characteristic of the species.

Several techniques have been used to determine the spawning type of fish. The total spawning has been characterized by the synchronous oocyte development (West, 1990), presence of unyolked oocyte beside empty follicles (RIZZO et al., 1996; RICARDO et al., 1997) and the distribution of the oocyte diameters frequency shows two defined modes (SANTOS et al., 1996). However, De Vlaming (1983) mentioned that the distribution of the oocyte diameters frequency measured from histology is tendentious, probably because only oocytes sectioned through the nucleus are measured, and the probability of this to be present in a particular section is proportional to the nucleus diameter (WEST, 1990). 
The percentage of occurrence of the different oocyte types was determined by accounting all types of oocyte in histological slides of the gonads. This observation suggests that $L$. copelandii is a total spawner. The results coincide with those observed by Folguera (1981) for $L$. obtusidens in La Plata's River, and in several dams of Minas Gerais State, Brazil, like Tavares \& Godinho (1994) for L. piau in Três Marias Reservoir, Ricardo et al. (1996) for L. striatus in Furnas Reservoir, Rizzo et al. (1996) for Leporinus reinhardti (LÜTKEN, 1874) in Três Marias Reservoir and Diniz (1997) for the five species of Leporinus studied in Camargos Reservoir. However, Bazzoli (1992), by studying the oogenesis dynamics of 103 species of Brazilian teleosts, verified fractional spawning for L. amblyrhynchus, coinciding with other species of the family Anostomidae as S. knerii in Três Marias Reservoir (Ferreira \& Godinho, 1990) and $S$. nasutus in Furnas and Estreito Reservoir (BENJAMIN, 1996).

The reproductive processes generally exhibit endogenous rhythms triggered by environmental signals in order to fit the time of reproduction in a favorable development of the larvae and juveniles environmental time (BALDISSEROTTO, 2009).

One of the most important parameters of gonad's condition is its weight (NIKOLSKI, 1963). During the process of oocyte maturation, ovaries increase volume and, consequently, of weight (BAZZOLI \& GODINHO, 1991; VAZZOLER, 1996). The gonadosomatic relation (GSR) or gonadosomatic index (GSI) expresses the gonad weight as a proportion of body weight and it can be used as an efficient indicator of the ovarian functional stage (AGOSTINHO et al., 1990, VAZZOLER, 1996). This relation increases according to the progress of gonadal maturation process, whose peak coincides with the ovarian advanced maturation stage, and the smallest values are attributed to the rest stage (BENJAMIN, 1996; LAMAS \& GODINHO, 1996).

The value of GSR has been used as indicator of the functional stage of the ovaries for other Brazilian freshwater teleosts (ANDRADE, 1990; FERREIRA \& GODINHO, 1990; DINIZ, 1997). The GSI monthly values of females of Lactophrys quadricornis were associated to two different periods. One period demonstrated larger gonadal activity, and other, a spawning or rest stage (RUIZ et al., 1999). According to Nikolski (1963), the dynamics of this index is intimately associated to the spawning type of the species. For L. copelandii, the confidence intervals of the GSR average values for the rest and initial maturation stages were overlapped, indicating that this variable was not an efficient indicator of these two stages of the reproductive cycle for females captured in the study area. Such observation was also made by Delahunty \& De Vlaming (1980) and Lamas \& Godinho (1996) for Carassius auratus (L.) and Serrasalmus spilopleura respectively.

According to Diniz (1997), the spawning period begins, in the present study, soon after the peak of monthly GSR, in September. As reported by Nikolski (1963), the slope of the descending part of the GSR curve, after its peak, determines the extension of the spawning period in the species. When the descending inclination is abrupt, it indicates a short spawned period. However, in this work, in spite of the curve of monthly GSR presents abrupt fall from September until October, this didn't characterize a short reproductive period, once that spawned females with empty follicles were captured from November until March.

The spawned of Harttia loricariformis females (STEINDACHNER, 1876) occurred from September until February, mainly in September and October in the lower Paraíba do Sul River (MENEZES et al., 1998). This observation was coincident with the largest bimonthly averages of the gonadosomatic relation observed for $L$. copelandii in the present work. Females of $L$. copelandii were ready to spawning from September until February, time in that most of the species reproduces at the lower basin of Paraíba do Sul River (ENGEVIXFURNAS/FUJB/UFRJ 1991).

This reproductive behaviour of $L$. copelandii coincides with what is expected, since rainfall and high level of water are considered the major reproductive activity inducing agents in the 
tropical climates (SHANBHAG \& NADKARNI, 1979, apud RIZZO et al., 1996). In this work, the histological low occurrence of empty follicles in females of $L$. copelandii in spawning stage suggests that, probably, the study area doesn't represent the spawning place of this species.

\section{References}

AGOSTINHO, A.A.; G. BARBIERI; J.R. VERANI \& N.S. HAHN. Variação do fator de condição e do índice hepatossomático e suas relações com o ciclo reprodutivo em Rhinelepis aspera (Agassis, 1829) (Osteichthyes, Loricariidae) no rio Paranapanema, Porecatu, PR. Ci. Cult. 42: 711-714. 1990.

ANDRADE, D.R. Biologia reprodutiva da manjuba Curimatella lepidura Eigenmann \& Eigenmann, 1889 (Pisces, Curimatidae) da represa de Três Marias, rio São Francisco, MG. Tese de Doutorado, Universidade Federal de Minas Gerais, Belo Horizonte, Brasil. 217 p. 1990.

ARAÚJO, F.G.; A.C.A. SANTOS \& M.R.F. Simoni. Variação espacial e temporal da comunidade de peixes do médio e baixo rio Paraíba do Sul, RJ. Rev. Univ. Rural, Série Ciência da Vida. 17: 61-73. 1995.

ARAÚJO, F. G.; L. FICHBERG; B. C. T. PINTO; M. G. PEIXOTO. Variações espaciais na assembléia de peixes no Rio Paraíba do Sul (Barra Mansa, Barra do Piraí), Rio de Janeiro, Brasil. Revta bras. Zool. 18 (2): 483 - 492. 2001.

BALDISSEROTTO, B. Fisiologia de peixes aplicada à piscicultura. 2.ed. Santa Maria: Universidade Federal de Santa Maria, 350p. 2009.

BAZZOLI, N. \& H.P. GODINHO. Reproductive biology of the Acestrorhynchus lacustris (Renhardt, 1874) (Pisces, Characidae) from Três Marias reservoir. Zool. Anz. 226: 285-297. 1991.

BAZZOLI, N. \& E. RIZZO. A comparative cytological and cytochemical study of the oogenesis in ten Brazilian teleost fish species. Eur. Arch. Biol. 101: 339-410. 1990.

BAZZOLI, N. Ovogênese em peixes teleósteos neotropicais de água doce. Tese de Doutorado em Morfologia, Universidade Federal de Minas Gerais, Belo Horizonte, Brasil. 181 p. 1992.

BAZZOLI, N. Parâmetros reprodutivos de peixes de interesse comercial do rio São Francisco, região de Pirapora, MG, p. 286-300. In: Godinho H.P. \& A.L. Godinho (Eds). Águas, peixes e pescadores do São Francisco das Minas Gerais. Belo Horizonte, CNPq/PADCT, Editora PUC Minas, 440p. 2003.

BENJAMIN, L.A. Biologia reprodutiva e estudo ultra-estrutural da parede de folículos ovarianos de Schizodon nasutus (Pisces, Anostomidae) nos Reservatórios de Furnas e Estreito, Rio Grande, MG. Tese de Mestrado em Morfologia, Universidade Federal de Minas Gerais, Belo Horizonte, MG, Brasil. 135 p. 1996.

KOBELKOWSKY, A. Morphological Diversity of the Ovaries of the Mexican Teleost Fishes. Int. J. Morphol., 30(4):1353-1362. 2012. 
BEZERRIL, C.R.S.F.; L.M.N. ARAÚJO \& P.C. TOSIN. II. A ictiofauna: Diversidade biológica e padrões biogeográficos, p. 15-43. In ANEEL/CPRM (orgs.). Contribuição ao conhecimento da bacia do rio Paraíba do Sul - Coletânea de estudos. ANEEL/CPRM, Rio de Janeiro, Brasil. 1998.

CARVALHO, C.E.V.;, A.R.C. OVALLE; C.E. REZENDE; M.M. MOLISANI; M.S.M.B. SALOMÃO \& L.D. LACERDA. Seasonal variation of particulate heavy metals in the lower Paraíba do Sul river, RJ, Brazil. Environmental Geology. 37: 297-302. 1999.

CHAVES, P.T.C. \& A.E.A.M. VAZZOLER. Aspectos biológicos de peixes amazônicos. II. Anatomia microscópica de ovários, escala de maturidade e tipo de desova das espécies do gênero Semaprochilodus. Rev. Brasil. Biol. 44: 347-359. 1984.

DE VLAMING, V. Oocyte development patterns and hormonal involvements among Teleosts, p.176-200. In Rankin, J.C., T.J. Pitcher \& R.T. Duggan (eds.). Control Processes in Fish Physiology. Croom Helm, Australia. 1983.

DELAHUNTY, G. \&. V.L. DE VLAMING. Seasonal relationships of ovary weight, liver weight and fat stores with body weight in the goldfish, Carassius auratus (L.). J. Fish Biol. 16: 5-13. 1980.

DINIZ, C.C. Dinâmica reprodutiva de Leporinus striatus e histologia do ovário de cinco espécies do gênero Leporinus SPIX 1829 (OSTEYCHTHYES, CHARACIFORMES, ANOSTOMIDAE) na Represa de Camargos, MG. Tese de Mestrado em Produção Animal, Universidade Federal de Lavras, Lavras, MG, Brasil. 69 p. 1997.

ENGEVIX-FURNAS/FUJB/UFRJ. Levantamento da ictiofauna do rio Paraíba do Sul e ciclo reprodutivo das principais espécies, no trecho compreendido entre Três Rios e Campos. II: Aspectos reprodutivos da ictiofauna. ENGEVIX-FURNAS/FUJB/UFRJ, Rio de Janeiro, 190 p. 1991.

FERREIRA, R.M.A. \& H.P. GODINHO. Reproductive biology of the white-piau, Schizodon knerii (Steindachner, 1875) (Anostomidae) from a reservoir in southeast Brasil. Eur. Arch. Biol. 101: 331-344. 1990.

HIRT, L. M.; S.A. FLORES \& P.R. ARAYA. Reproduction and growth of Pimelodus clarias maculates (Lac.1803) Pimelodidae, Pisces, in the Upper Paraná River, Argentina: Reservoir effect. Acta Limnol. Bras., 17(3):301-315.

Folguera, S.T. Ciclo sexual y mecanismo de maduración del ovário de La Boga, Leporinus obtusidens. Ecologia. 6: 9-14. 1981.

GARAVELLO, J. C. Revisão taxonômica do gênero Leporinus SPIX, 1829 (Ostariophysi, Anostomidae). Tese de Doutorado em Zoologia, Universidade de São Paulo, São Paulo, Brasil. 455 p. 1979.

GARCÍA-CAGIDE, A. \& T. GARCÍA. Reproducción de Mycteroperca bonaci y Mycteroperca venenosa (Pisces: Serranidae) en la plataforma cubana. Rev. Biol. Trop. 44: 771-780. 1996. 
HOAR, W.S. Reproduction, p. 1-72. In W.S. Hoar \& D.J. Randall (eds.). Fish Physiology. Academic Press, London. 1969.

LAMAS, I.R. \& A.L. GODINHO. Reproduction in the piranha Serrasalmus spilopleura, a neotropical fish with an usual pattern of sexual maturity. Environ. Biol. Fishes. 45: 161-168. 1996.

LOPEZ, A.M.L.; M.C. LEYTON \& V.M.E. GRAF. Técnicas de Histología y Citología. Universidad de Chile, Facultad de Medicina, Chile. 242 p. 1982.

LUNA, L.G. Manual of Histologic Staining Methods of the Armed Forces Institute of Pathology. American Registry of Pathology, United States of America. 258 p. 1969.

MARENGO, J. A. \& L. M. ALVES. Tendências Hidrológicas da Bacia do Rio Paraíba do Sul. Revista Brasileira de Meteorologia, v.20, n.2, 215-226. 2005.

MENEZES, M.S.; J.M.R. ARANHA \& E.P. CARAMASCHIOcurrence and aspects of reproductive biology of Harttia loricariformis (Loricariinae) in the lower Paraíba do Sul river (Rio de Janeiro, Brasil). Acta Biol. Par. 27: 15-26. . 1998.

NIKOLSKI, G.V. The ecology of fishes. Academic Press, London. 352 p. 1963.

PRESTES, L.; M. G. M. SOARES; F. R. SILVA; D. R. BEVILAQUA; M. M. BITTENCOURT. Dynamic population of Triportheus albus, T. angulatus, and T. auritus (Characiformes: Characidae) in the floodplain lakes of Central Amazonian. Biota Neotropical, 10: 3, 177-181. 2010.

RICARDO, M.C.P.; C.A. AGUIAR; E. RIZZO \& N. BAZZOLI. Morfologia da micrópila e da célula micropilar em teleósteos neotropicais de água doce. Arq. Bras. Med. Vet. Zootec. 48: 17-24. 1996.

RICARDO, M.C.P., G.B. SANTOS; E. RIZZO \& N. BAZZOLI. Aspectos reprodutivos de Leporinus amblyrhynchus Garavello \& Britski, 1987 e Leporinus striatus Kner, 1859 (Pisces: Anostomidae) no reservatório de Furnas, MG. Bios. 5: 29-35. 1997.

RIEHL, R. Surface morphology and micropyle as a tool for identifying fish eggs by scanning electron microscopy. Microscopy and Analysis. 2: 29-31. 1993.

RIZZO, E. \& N. BAZZOLI. Oogenesis, oocyte surface and micropylar apparatus of Prochilodus affinis Reinhardt, 1874 (Pisces, Characiformes). Eur. Arch. Biol. 104: 1-6. 1993.

RIZZO, E.; Y. SATO; R.M.A. FERREIRA; H. CHIARINI-GARCIA \& N. BAZZOLI. Reproduction of Leporinus reinhardti Lütken, 1874 (Pisces: Anostomidae) from the Três Marias reservoir, São Francisco river, Minas Gerais, Brasil. Ci. Cult. 48: 189-192. 1996.

RUIZ, L.J.; M.R. FIGUEROA \& A.A. PRIETO. Ciclo reproductivo de Lactophrys quadricornis (Pisces: Ostraciidae) de la costa nororiental de Venezuela. Rev. Biol. Trop. 47: 561-570. 1999. 
SANTOS, G.B.; L.N.V. BARROS \& M.U. Menezes. Fecundity of the Astyanax bimaculatus (Reinhardt, 1874) (Teleostei, Characidae) from upper Rio São Francisco basin, Brazil. Arq. Bras. Med. Vet. Zootec. 48: 101-108. 1996.

SATO, Y. \& H.P. GODINHO. Adesividade de ovos e tipo de desova dos peixes de Três Marias, MG. Coletânea de resumos dos encontros da Associação Mineira de Aquicultura, 19821987, Brasília, Brasil. 102-103. 1988.

TAVARES, E.F. \& H.P. GODINHO. Ciclo reprodutivo do peixe piau-gordura (Leporinus piau Fowler, 1941) da represa de Três Marias, rio São Francisco. Rev. Ceres. 41: 28-35. 1994.

TAVARES, E.F. Biologia reprodutiva do piau-gordura Leporinus piau Fowler, 1941 (Pisces, Anostomidae) da represa de Três Marias, rio São Francisco, MG. Tese de Mestrado em Morfologia, Universidade Federal de Minas Gerais, Belo Horizonte, Brasil. 1986.

TELES, M.E.O. \& H.P. GODINHO. Ciclo reprodutivo da Pirambeba Serrasalmus brandtii (Teleostei, Characidae) na represa de Três Marias, rio São Francisco. Rev. Brasil. Biol. 57: 177184. 1997.

VAZZOLER, A.E.A. DE M. Biologia da reprodução de peixes teleósteos: Teoria e prática. NUPELIA, Maringá, Paraná, Brasil. 1996. 169 p.

WALLACE, R.A. \& K. SELMAN. Cellular and dynamic aspects of oocyte growth in teleosts. Am. Zool. 21: 325-343. 1981.

WEST, G. Methods of assessing ovarian development in fishes: a Review. Aust. J. Mar. Freshwater Res. 41: 199-222. 1990. 